\title{
Die Huidige Stand van die Etiek
}

\section{P S DREYER}

Wanneer ons na die daaglikse praktiese lewe van die gewone blanke Westerling kyk, blyk dit dat hy grotendeels lewe volgens die norme wat reeds baie geslagte lank geldig is. Binne menseheugenis het sekere veranderinge ingetree; daar is byvoorbeeld ' $n$ groter toegeeflikheid en verdraagsaam heid wat seksuele sake betref, ' $n$ groter selfstandigheid van kinders en jongmense teenoor hulle ouers, 'n groter emansipasie van die vrou en so meer, maar die ou norme van eerbied vir die menslike waardigheid, hulpvaardigheid, eerlikheid en so meer is nog steeds geldig. Selfs in 'n samelewing wat grootliks seksueel losbandig geword het, is die norme van egtelike getrouheid en kuisheid nie heeltemaal tot niet nie.

Wat hier gesê is, geld die Blanke samelewing van Suid-Afrika, maar dit geld ewegoed die samelewings van die Wes-Europese lande.

Die geldigheid van die tradisionele norme kan 'n mens ook sien in die werke van etici. Aan welke etiese rigting die filosoof ook al mag behoort, en hoe ver hy van die tradisionele opvattings ook al mag afwyk, die voorbeelde wat hy gebruik, impliseer byvoorbeeld die afkeurenswaardigheid van leuens en die goedkeurenswaardigheid van eerlikheid. Die voorbeelde van die hedendaagse etikus verskil nie veel van die voorbeelde van etici van eeue gelede nie.

Hierdie feitelike situasie moet ons fundeer in die Christelike sedeleer soos ons dit vind in die Bybel, maar geïnterpreteer deur die kerk en gevorm deur baie eeue se tradisie. Selfs in die huidige situasie waarin ' $n$ baie groot deel van die Westerse mensdom vreemd vir die kerk geraak het, is dit nog steeds die geval. Daar is nog 'n baie groot deel van die Westerse mensdom wat bewus en aktief as gelowiges die Christelike sedeleer handhaaf. Daarbenewens is die Westerse regsisteme, die oorweldigende meerderheid van geldende wette, die instellinge van die samelewing - in kort die oorweldigend grootste gedeelte van die opset en orde van die Westerse samelewing ' $n$ erfenis uit die verlede en 'n skepping van die hede wat direk of indirek op die Christelike sedeleer gebou is. Verder het tweeduisend jaar van Christendom 'n lewenswyse, 'n praktiese fatsoenlikheid, 'n diep-gewortelde patroon van oortuigings en 'n tradisionele genormeerdheid geskep wat vir die Westerling vanselfsprekend is.

Dit is die praktiese situasie, maar sodra ons vra na die fundering van die praktiese fatsoenlikheid, verander die prentjie. Die man op straat word soms - veral deur konfliksituasies - gedwing om vir homself rekenskap te gee van die fundering van sy elkedagse sede- 
likheid. Wanneer die gewone man die vraag: Waarom is goed goed en sleg sleg? moet beantwoord, staan hy meesal verleë. Vir die revolusionêre gees van ons tyd geld antwoorde soos: "sommer!" of "'n ordentlike mens doen nie sulke dinge nie" of "dit is jou plig" nie meer nie. As hy dan na 'n vaste basis soek waarop hy kan terugval, ontdek hy 'n geestelike lugleegte. Hy voel dat sy norme geldig is, maar hy kan dit nie fundeer nie en daar is geen gesag waarop hy hom kan beroep om dit te regverdig en krag daaraan te verleen nie. Dit skep by hom verwarring en onsekerheid, nie net oor die fundering van die sedelikheid nie, maar ook oor die geldigheid van sy sedelike oortuigings en norme en oor die goed- of afkeurenswaardigheid van sy handelinge.

Die verwarring en onsekerheid van die gewone man kan ons baie goed verstaan wanneer ons na die etiek kyk. Die fundering van die sedelikheid is ' $n$ etiese probleem - nie in die sin dat die etiek 'n bepaalde fundering moet voorskryf nie, maar as 'n ontbloting en 'n beskrywing van die fondament waarop die sedelikheid inderdaad berus. Dit is ' $n$ historiese feit dat van hierdie fondament in die meervoud gepraat moet word, omdat etici in die verlede nie met mekaar saamgestem het nie en inderdaad verskillende funderings van die sedelikheid aangebied het. Dit is egter ewe goed' $n$ historiese feit dat die groot etici van die verlede (bv lm Kant) nie net self oortuig was dat hulle 'n objektiewe fundering vir die sedelikheid aangebied het nie, maar dat hulle ook baie wye aanklank met hulle werk gevind het. Wanneer ons na die hedendaagse etiese toneel kyk, is dit juis hier waar ons ' $n$ groot leemte ontdek: dit lyk asof 'n algemeen geldige fundering van die sedelikheid nie meer bestaan nie en nie meer aangebied kan word nie. Die etiek van die twintigste eeu het in die analise van die sedelike fenomene (die mens as sedelike subjek, vryheid, die sedelike handeling, die sedelike oordeel, waardes en norme en so meer) hoogtes bereik en nuwe bane ingeslaan soos nog nooit te vore nie. So hoog soos die etiek op hierdie terrein staan, so laag staan die etiek ten opsigte van die fundering van die sedelikheid. Dit werk deur nie net in die kringe van die etici nie, maar ook tot by die man in die straat en werk mee tot die sedelike lamheid en verwarring van ons tyd.

Nou mag dit lyk asof ek van mening is dat die etiek 'n fundering van die sedelikheid moet verskaf en voorskryf, sodat dit die taak van die etikus is om die man op straat sy sedelike ruggraat terug te gee of regop te hou. Dit is geensins die geval nie. So 'n fundering is die geloof of die diepste oortuigings wat die grondslag van ' $n$ sedeleer is en dit is nie die taak van die sedekunde om 'n sedeleer voor te skryf nie. Wat ek egter wel wil beweer, is dat die etiek met sy kritiese werking die funderings van die verlede help vernietig het, sonder dat daar iets in die plek daarvan gekom het. Op negatiewe wyse het die etiek 
'n groot bydrae gelewer tot die angs en die nood van die ongeborgenheid van ons tyd. Wanneer ons dit raaksien, verstaan ons die etiek van ons tyd beter.

Om hierdie venster op die etiek oop te stoot, wil ek die probleem soos volg van naderby formuleer:

Ten diepste is goed en kwaad die tema van die etiek. Ontologies is goed en kwaad wesenlik van menswees, sodat die wesenlike openheid van die mens altyd die tweespaltende moontlikheid van goed en kwaad insluit. Sedelik word goed en kwaad in die norme as meetsnoere en rigsnoere uitgedruk. Die norme bring die ope moontlikhede van beide goed en kwaad tot spreke en konkretiseer dit in die elkedagse lewe van die mens en sy samelewing. Die opeisende krag van die norm hou die mens aan die een kant gedurig in hoogspanning - die hoogspanning van die behoorlikheidseis in die aangesig van die kwaad en die gewetensaanklag in die aangesig van die goeie. Aan die ander kant is die opeisende krag van die norme tegelykertyd die grond van menslike geborgenheid, vastheid en sekerheid. Wanneer die norme onvas word, aan die swewe raak, is dit ' $n$ teken dat goed en kwaad aan die swewe is en daarmee saam die eksistensie van die mens. Dan is die mens uitgewerp in die niks en oorgegee aan eksistensiële vertwyfeling.

Etiek word gewoonlik gedefinieer as die wetenskap van die sedelikheid. Dit val uiteen in die hoofprobleemgebiede van die analise van die sedelikheid self as uitsluitlik en wesenlik menslik, waarin ons moet opereer met die fundamentele kategorieë van menswees, maar waarin ons elke keer gekonfronteer word met die fundamentele verskil tussen goed en kwaad en die allesoorheersende betekenis van hierdie verskil; tweedens die analise van waardes en norme wat altyd in sedeleringe verband optree en wat die meetsnoere en rigsnoere van die mens se beoordeling en handeling is, maar wat die stellingname van die mens binne die oop moontlikhede van goed en kwaad is; derdens die analise van die sedelike handeling, wat juis as sedelike handeling steeds in die lig van goed en kwaad staan; vierdens die analise van die sedelike oordeel en die sedelike redenasie, wat eweneens in die lig van goed en kwaad moet staan; en laastens die realisering van die sedelikheid in die praktyk van die samelewing, waar dit weer eens gaan om wat goed en kwaad is.

Hieruit blyk waarom hierbo gesê is dat die tema van die etiek ten diepste goed en kwaad is. Baie faktore het vanaf die begin van die Moderne Tyd maar veral in die twintigste eeu meegewerk om van goed en kwaad 'n probleem te maak. Die etiek is een van hierdie faktore maar tegelykertyd is die etiek ook in ' $n$ groot mate die resultaat van al die meewerkende faktore. Om 'n visie op die huidige stand van die etiek te kry, wil ek daarna kyk vanuit die hoek van goed en kwaad wat'n probleem geword het. Wie enigsins op hoogte van sake 
is, sal weet dat dit binne die bestek van 'n voordrag soos hierdie onmoontlik is om enigsins na volledigheid of breedvoerigheid te strewe in die bespreking van die ter sake faktore. Ek wil egter die volgende faktore wat ek as die belangrikste beskou, ter sprake bring:

1 Die verlies aan gesag van die kerk, die Christelike godsdiens en veral die Bybel. Baie faktore het hiertoe meegewerk, ook die faktore wat hieronder genoem word. Wat ek hier in besonder wil noem, is die wyse waarop kerke en teoloë self met mekaar en met die Bybel te werk gegaan het. Sedert die Renaissance, maar veral sedert die middel van die negentiende eeu lyk dit soms asof 'n soort kannibalisme en doodsverlange van kerke en teoloë besit geneem het. Wanneer die kerk en die teoloë so dikwels die agteruitgang van die gesag van die kerk, die Christelike godsdiens en die Bybel beklaag, plaas hulle ook hulleself in die beskuldigdebank.

Hierbo het ons aangetoon dat die norme waarvolgens die Westerling leef, op die Christelike godsdiens en die Bybel teruggevoer kan word. Met die verval van die gesag van die kerk, die Christelike godsdiens en die Bybel bly die onderskeiding van goed en kwaad as tradisionele norme van die praktiese lewensvoering voortbestaan, maar die fundering daarvan het verval.

2 Sedert die begin van die twintigste eeu is daar oor die hele linie van die intellektuele aktiwiteit van die Weste ' $n$ besliste wegbeweeg van die metafisika. Sedert die begin van etiese nadenke by die Grieke was sedelike goed en kwaad ingevoeg in die synsordening. Die synsorde het die realiteit van goed en kwaad gewaarborg; sedelike eise het die krag van 'n kosmiese orde agter hulle gehad; skuld het ook'n kosmiese betekenis gehad; en die belangrikste van alles: die syn en die synsorde self was ten diepste van sedelike aard. Dit is die geval byvoorbeeld met Plato se hoogste Idee, die Idee van die goeie of God, wat as allesomvattende werklikheid die hele kosmos deurstraal met die goedheid, skoonheid en waarheid van die hoogste Idee. Hierdie beskouing van Plato, die grondlegger van die Westerse idealisme, bly'n grondtrek van die Westerse metafisika deur die geskiedenis heen. Dit geld ook Fichte wat die verhouding probeer omkeer: Aan die begin staan die daad, sê Fichte en hiervandaan uit moet die synsordening gesien word. Juis hierdie benadering dra egter 'n sedelike element in die syn en die synsordening in.

Wanneer die metafisika oorboord gegooi word, is daar geen hoogste Idee (Plato), geen Godgeskape, rasioneel geordende universum (Thomas), geen Deus sive natura (Spinoza) of enige syn of synsordening meer oor wat aan goed en kwaad 'n plek en 'n gesag gee nie. Dit werk dwarsdeur die hele etiek, tot in ons eie tyd toe: Im. Kant word nog steeds erken as een van die grootste etici wat ooit geleef het, maar Kant se fundering van die sedewet in 'n universele 
rede, die Maximen as formele, universeel geldende praktiese beginsels wat uit die redelikheid spruit, die Reich der Zwecke as die ideale samelewing van mense wat gehoorsaam aan die kategoriese imperatief leef, die Ding an sich as ontologiese fundering van vryheid as menslike werklikheid, en so meer, kan eenvoudig nie meer stand hou nie. Max Scheler en Nicolai Hartmann word nog steeds bestudeer en aangehaal, maar enige vorm van waarde-realisme het kragteloos geword en die materiële waarde-etiek het byna al sy aanhangers verloor. En by al die goeie dinge wat $G$ Heymans gedoen het, gee sy psigo-monisme as fundering van die etiek blyke dat Heymans die gees van sy tyd eenvoudig nie geken het nie.

3 Oor die effekte en betekenis van die ontwikkeling van die natuurwetenskap en tegniek is en word so baie geskryf dat ek baie kortliks daarby wil stilstaan. Ek wil net op die volgende wys:

3.1 Gedurende die afgelope paar eeue is die natuurwetenskap (myns insiens ten regte) as waardevry beskou. Eise en probleme van sedelikheid is nie natuurwetenskaplike probleme nie, die natuurwetenskap kan niks daaraan doen nie en vanuit die sedelikheid kan geen beperkings of rigsnoere aan die natuurwetenskap gestel word nie. Die tegniek is 'n uitvloeisel van die natuurwetenskap en is eweeens waardevry. Die tegniek, net soos die natuurwetenskap, is self baie hoog waardeer: tot die Eerste Wêreldoorlog is dit gesien as die middel tot onbegrensde vooruitgang. Sedert die Eerste Wêreldoorlog word dit ook negatief beoordeel as middel tot verwoesting en verslawing van die mens, maar tot hede vandag toe is die waardering oorweldigend positief: dit bring vooruitgang, welvaart, gerief, noodsaaklike dienste en dit is selfs 'n bestaansvoorwaarde vir die krioelende en steeds vermeerderende mensemassas van vandag.

Ons kan met Denis de Rougemont instem: die atoombom is nie goed of sleg nie; net die mens wat die atoombom gebruik of nie gebruik is, is goed of sleg. Desondanks is dit ' $n$ feit dat 'n baie groot deel, miskien die grootste deel van die lewe van die meerderheid Westerlinge vandag in beslag geneem word deur, in diens staan van of afspeel binne die sfeer van die tegniek en dat almal se lewe diepgaande daardeur beïnloed word. Daarmee kom ons lewe te staan in die teken van sedelike onbetrokkenheid en irrelevantheid.

3.2 Die ontwikkeling van die tegniek het sedert die agttiende eeu 'n radikaal veranderde lewensbestaan en daarmee saam ' $n$ radikaal veranderde lewensgevoel tot stand laat kom. Die hoofkenmerk van hierdie nuwe lewensbestaan is die bestaan in groot opeengehoopte massas. Die tegniek maak so 'n bestaan moontlik, maar vereis ook so ' $n$ bestaan. Hieroor is ook so baie geskrywe dat ek nie lank daarby wil vertoef nie, maar net enkele aspekte met die oog op die etiek wil beklemtoon. 
Een van die kenmerke van die massas van die industriële samelewing is dat dit beweeglik is. Dit is mense wat van die platteland na die stad getrek het of wat baie maklik van een stad of werkkring of woonplek na ' $n$ ander verhuis. Dit bring ' $n$ baie groot mate van anonimiteit mee en daarmee ' $n$ losheid van bindinge aan die medemens. Verder sny dit die mens grootliks los van sy historiese wortels en maak hom 'n wese van die oomblik wat hoofsaaklik op materiële waardes toegespits is. Die noodwendige gevolg hiervan was ' $n$ verandering in rangorde van waardes en van geldige norme. In WesEuropa was hierdie verandering baie meer radikaal as in SuidAfrika: die stede in Wes-Europa is baie groter en die industriēle rewolusie eeue ouer as by ons; daarby geld die boere as die laagste stand in Wes-Europa, sodat die stedelike bestaan 'n verbetering en verhoging van status meebring, terwyl dit by ons net omgekeerd is: die boer is die adel van die land, die bestaan op die plaas ' $n$ ideale lewenswyse en die trek na die stad 'n "come down".

Die massabestaan maak ook massabeheer noodsaaklik en dit word ook weer deur die tegniek moontlik gemaak. Hoe groter die massa, hoe groter die noodsaaklike mate van beheer. Nog belangriker is egter die beheer by wyse van die organisasie. Parallel met die masjien moet die menslike organisasie loop. Eers die kombinasie van meganisasie en organisasie maak die hedendaagse industrie moontlik. Organisasie is die menslike parallel van meganisasie, maar die primêre lid van hierdie kombinasie is die masjien, omdat dit die werklike produseerder is. Die ritme van die werker se lewe, sy lewensomstandighede, en sy status word deur sy posisie in die organisasie bepaal. Dit alles maak van die lewe, maar veral van verantwoordelikheid ' $n$ saak van gerasionaliseerde beplanning. Vryheid word 'n privaat aangeleentheid waarvoor ook deur die organisasie beplan word. Persoonlike verantwoordelikheid buite die verband van die organisasie is ook 'n privaat aangeleentheid wat vir die organisasie net van belang is in so verre dit die gladde werking van die organisasie mag belemmer. Binne die organisasie is die individu 'n vervangbare onderdeeltjie met instrumentele betekenis, wat die verlies van persoonlike waarde en menslike waardigheid impliseer.

Tradisioneel is die Westerse sedelikheid en etiek gebou op persoonlike vryheid en verantwoordelikheid, op die waarde van die individu en menslike waardigheid, en op die universele maar tegelykertyd intens persoonlike geldigheid van die sedelike waardes en norme. Na verskeie eeue van massabestaan begin dit duidelik word dat hierdie voorveronderstellings van die sedelikheid moeilik met die massabestaan versoenbaar is en skynbaar is daar in die Weste ' $n$ nuwe lewensgevoel en waardebesef aan die ontwikkel. 
4 Dit is egter nie net natuurwetenskap en tegniek wat tot die krisis van die etiek bygedra het nie, maar ook die geesteswetenskappe. Ek wys net op die volgende:

4.1 Die sosiologie: ' $n$ baie belangrike aspek in die etiek is dat die mens gebore word in ' $n$ samelewing waarbinne waardes en norme geldig is. In gehoorsaamheid aan hierdie waardes en norme verwag en ontvang die samelewing die nuwe mens, vorm hom en gee hom 'n plek in die samelewing. Van sy kant neem die individu sy plek in die samelewing in deur die waardes en norme van die samelewing tot sy eie te maak d w s deur dit te aanvaar as sy norme waaraan hy gehoorsaam moet wees en as hy nie daaraan gehoorsaam is nie, staan hy skuldig voor sy eie gewete, voor sy medemens en voor God. Die hedendaagse sosiologie erken hierdie gebeure as uiters belangrik, maar noem dit die "sosialiseringsproses". As proses is dit nie goed of sleg nie en het dit nie sedelike implikasies nie. Die belangrikheid van die sosialiseringsproses lê daarin dat die individu so glad as moontlik as funksionele onderdeel van die sosiale geheel moet inskakel en aanhou funksioneer. As dit nie gebeur nie, word die doeltreffendheid van die individu en die samelewing versteur met allerlei ongewensde gevolge.

4.2 Die geskiedenis en die volkekunde: sedert Xenophanes en Herodotus is die Westerse mens bewus daarvan dat verskillende samelewings verskillende waardes en norme handhaaf. Desondanks is die etiese relativisme 'n moderne verskynsel wat baie sterk deur die historisme en in die jongste tyd deur die volkekunde gevoed is. Ondanks alle interpretasies van die relativisme om die teendeel te probeer bewys, beteken iedere ware etiese relativisme dat die geldigheid van die waardes en norme kragteloos gemaak word. In ons eie tyd het die relativisme in so ' $n$ mate na die man op straat deurgewerk dat hy eintlik meer relativisties as die meeste etici geword het. Die resultaat hiervan is dat sedelikheid 'n volledig private aangeleentheid geword het. Volgens watter norme ek leef, is my privaat saak, waarmee niemand anders iets te doen het nie, terwyl ek van my kant ook geen sedelike eise aan ander - selfs nie eers aan my eie kinders kan stel nie.

4.3 Die psigologie: veral die psigo-analise het goed en sleg, skuld, gewetenswroeging en so meer psigologiseer, dit wil sê verklaar in terme van natuurlike psigiese prosesse. Dat hier 'n veld vir die psigologie is, ontken niemand nie, maar feit is dat die psigologiese verklaring van so ' $n$ aard was en is dat dit die spesifiek sedelike wegverklaar. Vir die etiek is byvoorbeeld skuld 'n ontologies-antropologieseksistensiële kwessie; vir die psigologie is dit skuldbewussyn en skuldgevoel, wat nie verkeerd is nie, maar waaruit die afleiding gemaak word: ek is nie skuldig nie, ek voel maar net so. 
5 Sedert die Eerste Wêreldoorlog leef die wêreld, meeste van almal die Weste, in die greep van ideologieë, waarvan die Marxisme en Kommunisme die belangrikste is. Nogmaals ter wille van die kortheid maak ek net enkele opmerkings oor die betekenis van die ideologiese bewegings vir die etiek.

5.1 In die jongste tyd het die beskouings van Karl Marx miskien meer as enigiets anders bygedra tot ' $n$ relativisme in die etiek. Marx se beskouing dat sedelikheid 'n klassemoraal is, ' $n$ deel van die bowebou wat bepaal word deur en afhanklik is van die ekonomiese en eiendomsverhoudings as onderbou en wat verander al na gelang die onderbou verander, maak van die sedelikheid 'n soort neweproduk van die ekonomiese prosesse. Baie skrywers sien Marx as gedrewe deur 'n sedelike hartstog, naamlik die verontwaardiging oor al die onreg en onderdrukking wat in die samelewing van sy tyd bestaan. Dit sou dan meebring dat die Marxistiese teorie in wese ' $n$ etiese teorie is omdat dit op sedelike motiewe gefundeer is. Dit is hier nie die plek om die korrektheid van hierdie siening te bespreek nie, maar wat buite twyfel staan, is dat die Marxistiese teorie die sedelikheid afhanklik maak van en laat bepaal deur a-sedelike faktore.

5.2 Westerse sedelike praktyk en beskouings word bo alles bepaal deur die Christelike godsdiens, en die intrinsieke waarde en die persoonlike verantwoordelikheid van die individu. Dit is welbekend dat die Marxisme die Christelike godsdiens verwerp en beveg, die individu geheel en al aan die klas ondergeskik maak en persoonlike verantwoordelikheid heeltemal in terme van klassebelange sien.

5.3 Dit is ook welbekend dat kommunistiese agitasies en rewolusies in die naam van vryheid gevoer word, maar dat onder ' $n$ kommunistiese bewind die tradisioneel Westerse idee van vryheid nie toegelaat word nie. Wat egter baie interessant en belangrik is, is dat die intellektuele kringe en die jeug van die Weste oorweldigend sterk Marxisties geword het. As gevolg van die vryheid van denke in die Weste, toon die Westerse Marxisme 'n geweldige wye spektrum van beskouings, wat dikwels radikaal van mekaar verskil. Hoe ver hierdie sogenaamde Neo-Marxiste ook al van mekaar verskil, een ding het hulle gemeen en dit is hulle beheptheid met die idee van vryheid. Hulle idee van vryheid is egter die tradisionele Westerse idee van vryheid en nie die Marxistiese en kommunistiese idee van vryheid nie. Die etiek van die verlede het altyd die gedagte van vryheid onlosmaaklik met die gedagte van verantwoordelikheid verbind. Kenmerkend van die Neo-Marxistiese beskouings (bv die Frankfurter Schule) is egter die beklemtoning van 'n negatiewe vryheid, dit wil sê vryheid van enige vorm van dwang. Dit word uitgewerk in ' $n$ byna anargistiese beskouing wat enige vorm van sosiale orde met argwaan beskou, omdat dit allerlei vorme van dwang im- 
pliseer. Verder het hierdie beskouinge 'n baie sterk rewolusionêre tendens en dan wel in die sin var ' $n$ kulturele of totale rewolusie: die sosiale orde of Establishment is dermate ' $n$ in mekaar geweefde totaliteit dat die geheel radikaal omver gewerp en verander moet word. Eers daarmee kan die Entfremdung, die verknegting waarin almal vasgevang is, opgehef word. Dit is alles egter nog negatief en baie vrae bly oor: Wat is dit wat tot stand gebring moet word? Hoekom sal dit goed wees of beter wees as die huidige bestaande? Volgens watter norme word hierdie "goed" of "beter" gemeet? Die NeoMarxistiese antwoorde op hierdie vrae is uiters vaag en al waarvan ons seker kan wees, is dat goed en kwaad soos die Weste dit altyd geken het, nie meer geld nie.

5.4 Ek kry die indruk, al is dit nie soseer by etici nie, dat daar by baie mense ' $n$ sinisme bestaan. Dit is die houding: niks is meer geldig nie; goed en kwaad bestaan nie meer nie; al weet ek dus dat dit nie werklik gefundeer is nie, plaas ek my op die standpunt van 'n bepaalde ideologie en hiervandaan werk ek die teoretiese en praktiese konsekwensies uit. Daarmee het ons 'n soort rasionalistiese sofistiek wat vir die sedelikheid vernietigender gevolge kan hê as aweregse beskouings wat uit geloof en oortuiging verkondig word.

6 Baie skrywers, onder andere Walter Schulz in sy Philosophie in der veränderten Welt, praat van 'n "veranderde lewensgevoel" in die Weste. Baie ander praat van 'n nuwe fase of periode van die Westerse geskiedenis wat ons betree het. Hoeveel waarde 'n mens hieraan moet heg, is moeilik om te sê omdat dit nog te naby aan ons is. Wat egter waar is en waargeneem kan word, is dat ons met verskynsels te doen het wat moontlik op radikale veranderinge dui. Kenmerkend van die verskynsel is dat ons dikwels met skynbaar onversoenbare kontradiksies te make het. Jeugbewegings soos die Jeug-vir-Christus-beweging en hippies, verskynsels soos die verskillende soorte musiek wat ons onder die jeug kry (Rock, punk, psigedeliese musiek en so meer), protesaksies, politieke aksies, dwelmgebruik, die onskuldigverklaring van seksualiteit, naaktheid en so meer, is alles verskynsels wat lyk asof daar 'n prysgawe van persoonlike identieit ten gunste van 'n anonimiteit in die groep is, maar tegelykertyd ook 'n hartstogtelike soek na persoonlike identiteit; daar is 'n prysgawe en aftakeling van die demokrasie en tegelykertyd 'n eis om al groter demokratisering op alle gebiede (bv die onderwys); daar is 'n gesoek na 'n nuwe natuurlikheid, ' $n$ onmiddellike belewenis van die natuur en die ek en 'n verwerping van die kunsmatigheid, oordadigheid en gekunsteldheid van die tegnokratiese wêreld maar tegelykertyd word daar op die tegniek staat gemaak om die mens groter vryheid te gee; daar is ' $n$ totale verwerping van die tradisionele Westerse idee van vryheid en al die instellings wat geskep is om daardie vryheid te be- 
waar en beskerm, maar daar is tegelykertyd ' $n$ hartstogtelike geroep om vryheid; daar is ' $n$ totale verwerping en aftakeling van alle tradisionele sedelike waardes en norme, maar tegelykertyd 'n hartstogtelike soektog na vrede, vryheid, geregtigheid, gelykheid en ander sedelike waardes; daar is die "opting out" uit die Establishment en alles wat dit verteenwoordig, maar tegelykertyd 'n intense behoefte om betrokke te wees - Ons laat dit daar. Wat uit al hierdie dinge gebore gaan word, kan niemand sê nie. Wat egter duidelik is, is dat die tradisionele sedelikheid van die Weste radikaal aan die verander is en dat goed en kwaad nuwe betekenisse kry.

7 Die laaste verandering waarop ek wil wys, is die ondergeskikstelling van die sedelikheid aan die eise en behoeftes van die oomblik. Ons kan dit soos volg formuleer:

By alle individue en groepe bestaan daar 'n wye verskeidenheid van behoeftes wat kan strek vanaf die mees elementêre fisiese behoeftes tot by die hoogste vorme van geestelike vryheid. Behoeftes is die grond van konfliksituasies wat 'n vreedsame en gelukkige saambestaan tussen individue, groepe en samelewings tot op internasionale vlak onmoontlik kan maak. Sedelikheid in die vorm van geldige beginsels, waardes en norme beteken niks om hierdie konfliksituasies te vermy of waar dit reeds bestaan, uit die weg te ruim nie. Trouens, sedelike beginsels, waardes en norme kan selfs grootliks tot sulke konfliksituasies bydra. Wat ons nodig het, is praktiese optrede om konfliksituasies te vermy of uit die weg te ruim. Die enigste moontlikheid om dit reg te kry, is deur te rasionaliseer: behoeftes moet onderskei en erken word (bv toestande van gebrek, onderdrukking van minderhede en so meer) en oplossings moet daarvoor gevind word (bv deur praktiese hulp wat gegee word, kompromieë en so meer).

Nou is dit ' $n$ baie ou gedagte dat praktiese doeltreffendheid belangriker is as sedelike beginsel of norm, dat kwaad die daaglikse tekortkominge en goed die uitskakeling van die tekortkominge is. Dit lyk my egter asof dit in die tweede helfte van die twintigste eeu ' $n$ dominerende element in die etiek geword het.

Op hierdie stadium wil ek die tema van die veranderinge in die sedelike bewussyn van die Westerse mens daar laat en baie kortliks stilstaan by enkele belangrike etiese rigtings van ons tyd.

1 Heel eerste wil ek opmerk dat wat hierbo gesê is, nie beteken dat die klassieke etiese temas en sedelerige sisteme verdwyn het nie. Die hedendaagse etiek wy nog steeds aandag daaraan en daar is nog steeds etici wat as kantiane, eudaemoniste en so meer beskryf kan word.

2 Kenmerkend van ons tyd is die groot aantal werke van historiese aard. Sulke werke is noodsaaklik en belangrik en moet verwelkom 
word. Desondanks kan ons die vraag stel of die groot belangstelling in die geskiedenis van die etiek nie dalk ' $n$ simptoom van radeloosheid met die huidige situasie is nie.

3 Hoewel die situationisme nie die etiese rigting met die meeste aanhangers is nie, is dit buitengewoon simptomaties van ons tyd. Die situationisme spruit veral uit die eksistensiefilosofie en word gedra deur dieselfde faktore wat die eksistensiefilosofie een van die belangrikste filosofiese bewegings van ons tyd gemaak het. Gesien van etiese kant lê die groot klem op die mens as vryheid. Waar die gedagte radikaal en konsekwent deurgevoer word (soos in Sartre se L'Existentialisme est une humanisme waarin die veelbesproke dilemma van die student voorkom), lei dit tot die beklemtoning van die situasie waarin die sedelike beslissing gevel moet word en waardeur die wesenlike vryheid van die mens openbaar word. Hierdie beslissing kan nie volgens universeel geldende norme van watter aard ook al gevel word nie, omdat 'n keuse volgens sulke norme 'n verloëning van die eie vryheid en 'n ontduiking van die eie verantwoordelikheid is. Die mens wat hiervolgens handel, is onopreg, "uneigentlich" en 'n lafaard. Daar is ook geen tekens of aanduidings van hoe ' $n$ mens in die konkrete situasie moet kies nie, want elke situasie is uniek en elke mens is uniek. Algemeen geldende norme en waardes is geen teken nie, omdat wat mense sê, glo en bely nog niks sê nie; wat goed is, word deur die vry beslissing in die unieke situasie bepaal. Daarbenewens is elke situasie só uniek dat dit hoogs twyfelagtig is of en hoe die algemeen geldende waardes in die bepaalde situasie geldig kan wees. Die moontlike gevolge van die keuse is ook geen teken nie, omdat dit in die eerste plek onseker is en tweedens grotendeels buite ons mag lê. Gevoelens en instinkte is geen leidraad nie, omdat die sterkte van ' $n$ gevoel nie gemeet kan word nie en omdat ons die gevoelens meesal ook eers moet interpreteer. Raadgewinge van vriende, aanduidings uit die Bybel, bepaalde, ervaringe wat ons gehad het en so meer is ook geen teken nie, omdat ons dit alles eers moet interpreteer, wat weer daarop neerkom dat ons kies.

Baie etici wat' $n$ etiese relativisme aanhang, vind sterk aanklank by die situationisme. Teoloë, veral uit die kringe van die dialektiese teologie, is situationiste omdat hulle al die klem lê op die beslissing wat elke keer opnuut voor God geneem moet word.

In die opset van hierdie lesing is ' $n$ kritiek op die situationisme nie ter sake nie. Tersaaklik is wel om daarop te wys dat ons hier met iets heeltemal nuuts in die geskiedenis van die Westerse etiek te doen het. Enige vorm van metafisiese, godsdienstige (in die geval van nieChristene) of tradisionele begronding ontbreek nie alleen nie, maar daarmee saam word elke vorm van universele geldigheid van waardes en norme prysgegee. 
4 'n Baie belangrike en in die Engelse taalgebied oorheersende stroming in die etiek is die taalanalitiese benadering. Gemeenskaplik aan al hierdie etici is dat hulle almal neo-positiviste is. Die ouer geslag van die taalanalitiese etici was geneig om die etiek uit filosofiese besinning uit te sluit, omdat 'n wetenskaplike benadering (in hulle sin van die woord) van sedelike fenomene nie moontlik is nie. Die jonger taalanalitiese etici gee hierdie standpunt prys, omdat die daaglikse spreektaal vol van waarde-uitsprake is. Die basiese uitgangspunt is egter dat hierdie etici hulle nie met die werklikheid van sedelike verhoudinge, handelinge en so meer besig hou nie, maar met die uitsprake oor hierdie werklikheid. Dit grond aan die een kant in die afwysing van die besinning oor die werklikheid omdat dit metafisika sou wees en aan die ander kant die strewe na'n wetenskaplike dit wil sê objektiewe en rasionele benadering van die sedelikheid. In die jongste tyd sien ons ook die begin van 'n deurbraak deur hierdie houding: verskillende etici het voel-voel uitbeweeg uit die blote taalanalise na besinning oor die fenomene waaroor die uitsprake gaan. Of hierdie wending werklik 'n deurbraak is en hoe ver dit sal gaan, sal ons nog moet sien.

Taalanalitiese werk het ons reeds in die dialoë van Plato en in die werke van Aristoteles. Die hedendaagse taalanalitiese benadering is egter iets nuuts omdat dit gepaard gaan met 'n bewuste verwerping van die metafisika, wat vroeër nie die geval was nie. Die taalanalitici het baie belangrike werk gedoen en baie nuwe insigte gebring. Desondanks kry 'n mens die gevoel dat hulle die nood van ons tyd en die bankrotskap van die etiek nie raaksien nie of nie wil raaksien nie. Hulle is soos die teoloë van Konstantinopel van 1453: terwyl die Mohammedaanse Turke besig was om die poorthekke van Konstantinopel oop te dwing, was die teoloë besig om ernstig te debatteer oor die vraag of Maria na die geboorte van Jesus nog 'n maagd was.

5 Verreweg die oorheersende sedelike tendens van ons tyd is die utilitarisme, hoewel dit baie dikwels nie so genoem word nie. Bentham, wat in 1832 dood is, is in 'n baie aktuele sin een van die baie belangrike hedendaagse filosowe. Sy beginsel van "utility" interpreteer hy self as "happiness" wat gewoonlik die beginsel van "the greatest happiness for the greatest number" genoem word. Die wyse waarop Bentham die beginsel hanteer, is onverfynd en ongesofistikeerd. So geld geluk of genot as meetbare grootheid wat afgeweeg kan word teen pyn. Welke kritiek 'n mens ook al teen Bentham se beskouing kan inbring, dit het 'n paar uitstaande kenmerke wat dit baie aantreklik maak: eerstens sluit dit aan by die daaglikse lewe en die gesonde verstand van iedere mens, naamlik dat ons gelukkig wil wees, graag ander mense gelukkig maak en daarvolgens handel; tweedens is dit 'n maklike praktiese reël wat elke mens kan verstaan 
en as rigsnoer kan gebruik; derdens is dit (soos Bentham in besonder bedoel het) 'n praktiese rigsnoer vir owerheidsliggame in die reëlings en wette wat vir die samelewing aanvaar word.

Ondanks alle kritiek wat op die utilitarisme uitgeoefen is, het dit nie net staande gebly nie, maar in die Engelstalige wêreld oorheersend geword. Die gevolg van die kritiek was egter dat die teorie van Bentham baie verfyn is - 'n gang van sake wat reeds deur J S Mill begin is. ' $n$ Baie belangrike aspek van hierdie ontwikkeling wat ek na vore wil bring, is die wending na 'n gesindheidsetiek wat binne die utilitarisme plaasgevind het. Een van die punte van kritiek op die utilitarisme is dat die gevolge van die handeling geluk tot maatstaf verhef word, terwyl die gevolge geensins in ons mag lê nie en inderdaad dikwels anders is as wat ons bedoel het. Die antwoord op hierdie kritiek is dat daar gelet moet word op die gesindheid van die dader: as iemand in goedertrou en met opregte bedoelings ' $n$ daad doen, kan ongewensde gevolge wat daaruit vloei en buite die beheer van die handelende persoon is, nie hom ten kwade toegereken word nie. Hoewel die gevolge van die daad afgekeur word, moet die dader nog steeds op grond van sy gesindheid as 'n goeie mens beoordeel word.

Ons leef in 'n tyd waarin - soos in die tyd van klassieke Griekeland - die grootste klem op die samelewing gelê word. Die mens se bestaan is noodwendig ' $n$ medemenslike, sosiale bestaan. Die geluk van die individu hang af van die aard van hierdie samelewing. Die hoogste prioriteit kom dus toe aan die probleem om 'n gelukkige samelewing te skep. "The greatest happiness for the greatest number" word op die wyse die universele norm. Die kritiek op die hedonisme, eudaemonisme en utilitarisme wat eeuelank uitgespreek is, naamlik dat genot of geluk in sigself nie sedelik goed of sleg is nie, verval daarmee en geluk word die enigste waarde wat intrinsiek goed is. Hierdie beskouing is vandag van die grootste belang, ook ver buite die kringe wat utilitaristies genoem word.

6 Ten nouste met die vorige punt hang die wending na 'n sosiale etiek saam. Aan die einde van die Middeleeue het die individualisme in die Weste opgekom en tot in ons eeu die Westerse denke oorheers. Die Westerse etiek was ' $n$ individualistiese etiek. Om hierdie rede was die verhouding van die individu tot sy mede-individu en tot die samelewing as geheel een van die belangrikste en lastigste probleme van die etiek.

Die twintigste eeu beleef ' $n$ fundamentele ommeswaai, wat algemeen is en nie tot sosialistiese en kommunistiese kringe beperk is nie: primêr staan nie die Ek nie, maar die Jy; voorop staan nie die individu nie, maar die samelewing. Soos in klassieke Griekeland is die moontlikheid en die praktiese verwerkliking van 'n regverdige en 
gelukkige samelewing die primêre probleem. Goed en kwaad kry op hierdie wyse ' $n$ dimensie wat dit laas in die Griekse filosofie gehad het, deurdat dit inhoud en betekenis in verhouding tot die samelewing kry. Vanuit hierdie dimensie kry goed en kwaad inhoud en betekenis vir die individu. Dit beteken dat sosiale, ekonomiese en politieke verhoudinge in plaaslike, nasionale en internasionale verband die hoofprobleme van die etiek word. Sosiale voorsiening, arbeidsverhoudinge, die mag van die staat, die armoede van die lande van die Derde Wêreld, rasseverhoudinge en so meer is die probleme waarmee die etiek hom besig hou, terwyl dit alles onder die eis van 'n konflikvrye, vreedsame en gelukkige samelewing vry van frustrasies staan.

Hoewel dit nie heeltemal nuut is nie, is die sosiale etiek vir ons tyd in so ' $n$ mate nuut dat dit ' $n$ hele reoriëntering in die etiese denke vereis. Op die oomblik ly dit egter nog aan 'n innerlike tweespalt wat eie aan 'n oorgangsfase is: aan die een kant dink die sosiale etiek in terme van die tradisionele individualistiese etiek en aan die ander kant in terme van 'n samelewingsgeoriënteerde etiek.

Ter afsluiting: ons leef in 'n tyd waarin goed en kwaad sosiologies, psigologies, ekonomies en polities verklaar en daarmee wegverklaar word. In hierdie wegverklaring grond die besondere kwaliteit van die hedendaagse vryheidsbegrip en hierop bou die grootste deel van die hedendaagse etiek.

Hierteenoor wil ek die werklikheid van goed en kwaad stel. Al sou ons die metafisiese aspekte van die werklikheid van goed en kwaad links laat, dan staan ons nog gekonfronteer met die antropologiese werklikheid wat geen eerlike denker mag miskyk nie. Dit is die werklikheid dat die mens wesenlik'n gesplete wese is. Vrede, geluk, reg en geregtigheid, goedheid en liefde is menslike moontlikhede, maar ewe reële en blywende moontlikhede is stryd, agressie, ongeluk, onreg, boosheid, haat en gruwelike wreedheid. Opvoeding, die lotgevalle van die menslike lewensloop, materiele en sosiale omstandighede, psigiese toestande en reaksies en so meer is alles baie belangrik. Dit plaas ' $n$ bepaalde individuele stempel op die mens, dit verklaar bepaalde verskynsels ten opsigte van die mens en gee ' $n$ bepaalde kwaliteit aan sy handelinge, maar dit kan die sedelikheid nie vervang nie. Die mens is 'n sedelike wese; sedelikheid is ' $n$ oerfenomeen van menswees, wat beteken dat die mens oerlik gekonfronteer is met die keuse tussen sedelik goed en sleg. Ewe oerlik staan die mens onder die pligsgebod om die goeie te doen en die bose te laat, terwyl daar'n radikale boosheid in die mens is wat hom neig tot die kwade. Die wegverklaar van goed en kwaad beteken nie dat die mens "jenseits von Gut und Böse" te staan kom nie, maar dat die mens sy vryheid probeer misbruik. Die wegverklaar van goed en kwaad los geen probleme op nie, maar skep talle ander. 
Aan die ander kant moet ons een ding goed besef: om terug te gaan in die geskiedenis is onmoontlik. Die ontwikkeling wat op ons eietydse situasie uitgeloop het, is ' $n$ werklikheid wat nie geignoreer kan word nie. In ons etiese nadenke sal ons daarvan rekenskap moet gee en daarmee rekening moet hou. Ek is om hierdie rede oortuig daarvan dat die etiek van die toekoms anders daar sal uitsien as die tradisionele etiek van die Weste. Ek is egter ewe oortuig daarrvan dat die etiek weer na die realiteit van goed en kwaad sal terugkeer. Ek is egter bevrees dat die terugkeer nie deur die etiek bewerk sal word nie, maar deur 'n baie onaangename lewenswerklikheid. 